\title{
Luxury knowledge : the Xiushilu ("Records of lacquering" of 1625
}

\section{Craig Clunas}

\section{(2) OpenEdition \\ 1 Journals}

Electronic version

URL: https://journals.openedition.org/tc/442

DOI: $10.4000 /$ tc. 442

ISSN: 1952-420X

Publisher

Éditions de l'EHESS

Printed version

Date of publication: 1 May 1998

ISSN: 0248-6016

\section{Electronic reference}

Craig Clunas, "Luxury knowledge : the Xiushilu ("Records of lacquering" of 1625", Techniques \& Culture [Online], 29 | 1998, Online since 28 October 2005, connection on 29 September 2022. URL: http:// journals.openedition.org/tc/442 ; DOI: https://doi.org/10.4000/tc.442

This text was automatically generated on 29 September 2022.

All rights reserved 


\title{
Luxury knowledge : the Xiushilu ("Records of lacquering" of 1625
}

\author{
Craig Clunas
}

